\title{
THE EFFECT OF CREDIT RISK ON BANK PROFITABILITY WITH EFFICIENCY AS THE INTERVENING VARIABLE
}

\author{
Eviyanti Yuanita Nur, Suhartono, Kristijadi Emanuel \\ STIE Perbanas Surabaya, Indonesia \\ *E-mail: yuanita.azzahra99@gmail.com
}

\begin{abstract}
This research is based on a bank, a law entity in which one of the main activities is lending. This study aims to analyze the credit risk, i.e. non-performing loan and allowance for impairment losses towards the profitability represented by bank return on asset with operating expense to operating income as the intervening variable. The technique of data analysis is statistical descriptive analysis of research variable, multiple regression analysis and path analysis which aim to measure the effect of intervening variable. The results of this study show that Non-performing loan ratio has positive and significant effect on operating expense to operating income efficiency ratio, ratio allowance for impairment losses has positive, but not significant effect on operating expense to operating income efficiency.
\end{abstract}

\section{KEY WORDS}

Credit risk, profitability, efficiency, intervening variable.

Bank is the largest financial institution in the world which main activities are funding and fund distribution in a form of credit for debtors (lending). Bad credit service and neglecting prudential principles can contribute to bank lose since the credit is highly risky which can affect the bank's performance; therefore, banking industry should be able to mitigate credit risk. The bank profitability development in Indonesia, from 2013 up to 2015, decreases because of the increase of Operating Expense to Operating Income and problem loans every year. Besides, domestically economic development in 2015 slowed down to $4.79 \%$ and the high lending on low quality loan causes the decrease of bank profitability. In this case, the credit risk scale can be seen in a form or Non-Performing Loan (NPL) ratio.

In Indonesian bank regulation which is made based on Statement of Financial Accounting Standard (SFAS) No.50 and 55, Allowance for Impairment Losses should be formed in order to overcome the lose risk; the higher funds being proposed to cover losses because of loan problems the higher Operating Expense to Operating Income efficiency. As a result, the profit is decreasing. These NPL and Allowance for Impairment Losses ratio is then used to measure the credit risk. The management of risk management, especially in good credit risk, will affect the profitability of a bank in which profitability used is Return on Asset (ROA) ratio.

Moreover, the increase of loan problems will affect the decrease of the ability in gaining profit. However, if it is followed by good efficiency management, it can affect the increase of profit. Regarding to the result of the previous studies, for instance a study conducted by Zou and Li (2014) who tested variable of Capital Adequacy Ratio (CAR) and Non-Performing Loan (NPL) to measure credit risk, and tested its profitability using Return on Asset (ROA) ratio and Return on Equity (ROE), stated that NPL affects significantly on ROA and ROE, whereas CAR does not significantly affect ROA and ROE; therefore, it can be concluded that the credit risk (NPL) positively affects bank profitability. On the other hand, Noman et al. (2015) states in their study that there is negative and significant impact on credit risk toward bank profitability in Bangladesh.

The main objective of this research is to analyze the effect of credit risk on bank profitability across efficiency as the intervening variable. This study uses credit problem NonPerforming Loan (NPL) and Allowance for Impairment Losses as the indicator variables representing credit risk, efficiency using Operating Expense to Operating Income, and using Return on Asset (ROA) ratio to measure profitability. Then, the research problems are: (1) 
does Non-Performing Loan (NPL) have positive, significant effect on Operating Expense to Operating Income efficiency ratio?; (2) does Allowance for Impairment Losses have positive, significant effect on Operating Expense to Operating Income efficiency ratio?; (3) does NonPerforming Loan (NPL) have negative, significant effect on profitability?; (4) does Allowance for Impairment Losses ratio have negative, significant effect on profitability?; (5) does Operating Expense to Operating Income efficiency have negative, significant effect on profitability?; (6) does Non-Performing Loan (NPL) have negative, significant effect on profitability with Operating Expense to Operating Income as the intervening variable?; (7) does Allowance for Impairment Losses ratio have negative and significant effect on profitability with Operating Expense to Operating Income as the intervening variable?

\section{THEORETICAL FRAMEWORK}

Credit Risk Theory. Fight (2004) states that credit refers to all credit types which should be returned with the interest by debtors based on the agreed agreement. In giving the credit, bank should be very selective and based on either internal or external applied regulations. Credit risk is a risk in which debtors fail to pay or they cannot fulfill their financial obligatory as it is agreed, (Hu, 2012). In this case, high credit risk of a bank shows the quality of credit level which is decreasing and it is likely to have higher default, (Jesus and Gabriel, 2006). The credit risk control aims to control all bank activities and bank credit activities so that it will not cause losses that exceed bank's ability or danger the continuity of the bank, (Berger and Udell, 1994). To avoid the loan problem, internal control in giving loan should be done.

Non-Performing Loan (NPL). Non-Performing Loan (NPL) or loan problem is the comparison between the total of loan problem and total credit given. The credit risk obtained by a bank is one of the risks of a bank caused by uncertainty in its return or caused by incompleteness of credit payment given by bank to debtors (Fight, 2004). In this case, the higher NPL or loan problem of a bank is the higher provision of earning assets. As a result, it can distract the performance of a bank, (Louzis et. al., 2012). Moreover, high NPL shows the poor quality of credit which can cause the number of loan problem is higher and cause bank losses in its operational activities which finally gives impact on the decreased profit (ROA)obtained by the bank (Kasmir, 2008).

Allowance for Impairment Losses. In 2016, there was a revision on the Statement of Financial Accounting Standards (SFAS) No.55 stating that Allowance for Doubtful Accounts was changed into Allowance for Impairment Losses. Allowance for Impairment Losses is a kind of proposal which should be provided by a bank with particular number of percentage which depends on nominal based on the classification of the quality of productive assets, (Hasan and Wall, 2004). If the loan from debtors decreases (impairment), a bank has to create funds or reserved funds for the loan. In this case, the result of credit evaluation is based on the decision made by every bank. Thus, each bank has its policy in forming reserved funds for the loan. Bank should consider of PPA of the productive assets and Allowance for Impairment Losses formed. If the calculation of PPA of productive assets is greater than of Allowance for Impairment Losses formed, bank should consider the difference which becomes the decrease of the modal. On the other hand, if the calculation of PPA of productive assets is less than the Allowance for Impairment Losses formed, bank is allowed to neglect PPA to decrease the modal, (Christensen et. al., 2008).

Operating Expense to Operating Income. Operating Expense to Operating Income belongs to earnings ratio. According to Kuncoro and Suhardjono (2002), "the success of a bank based on the quantitative evaluation towards bank earnings can be measured using operating expense on operating income". Moreover, Lukman (2005) says that "operating expense ratio is used to measure the level of efficiency and the ability of bank to do their operational activities". Operating Expense to Operating Income ratio is also well-known as efficiency ratio which is used to measure bank management ability in controlling Operating Expense to Operating Income. The lower the ratio is the more efficient the operating expense which is spent by a bank is; therefore, it can affect the increase of the ability of the bank in gaining profit. 
Profitability. Profitability is an ability of a company in gaining profit; the better profitability of a bank is the better the bank is in operating their business. According to Kasmir (2008), "Profitability ratio is a ratio to judge the ability of a company in gaining profit". Moreover, Irawati (2006) states that "profitability ratio" is a ratio to measure the efficiency of company's assets use or the ability of a bank to gain profit in particular period (commonly in semester, quarter, and many more) to see the ability of a company in operating the business efficiently". In this study, the profitability used is Return on Asset (ROA) ratio which refers to the comparison between the profit before tax payment and the average of total assets. The higher Return on Asset of a bank is the higher profit gained and the better use of the assets, (Malintan and Herawati, 2012).

Hypothesis Development. The basis of this study is the risk of bank management, especially credit risk. The researcher conducts a study about the relationship between credit risk and profitability with affectivity as the intervening variable. To achieve it, the researcher analyzes the effect of relationship between two indicators to represent or measure risk credit i.e. Non-Performing Loan (NPL) and Allowance for Impairment Losses and one indicator to represent profitability i.e. Return on Asset (ROA) ratio and the efficiency using Operating Expense to Operating Income as the intervening variable.

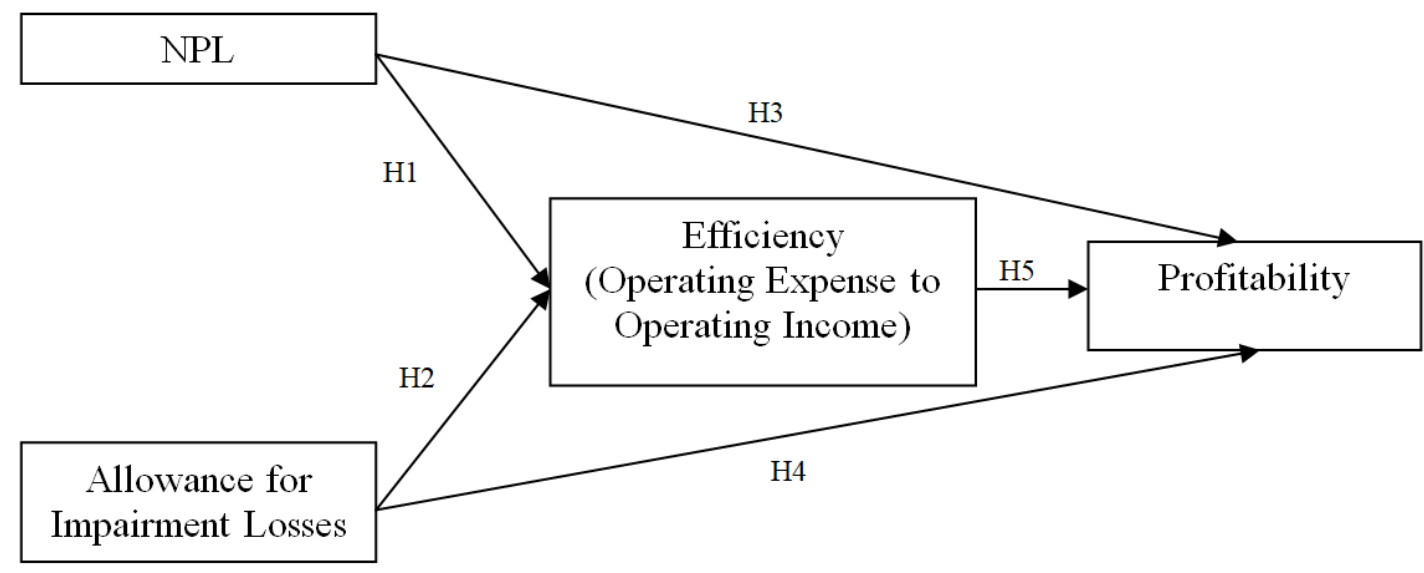

Figure 1 - Theoretical framework

Hypothesis 1: Non-Performing Loan (NPL) ratio has positive, significant effect on Operating Expense to Operating Income efficiency ratio.

Hypothesis 2: Allowance for Impairment Losses ratio has positive, significant effect on Operating Expense to Operating Income ratio.

Hypothesis 3: Non-Performing Loan (NPL) ratio has negative, significant effect on profitability.

Hypothesis 4: Allowance for Impairment Losses ratio has negative, significant effect on profitability.

Hypothesis 5: Operating Expense to Operating Income efficiency ratio has negative, significant effect on profitability.

Hypothesis 6: Non-Performing Loan (NPL) ratio has negative, significant effect on profitability across Operating Expense to Operating Income efficiency as the intervening variable.

Hypothesis 7: Allowance for Impairment Losses ratio negatively and significantly affects profitability across Operating Expense to Operating Income as the intervening variable.

\section{METHODS OF RESEARCH}

This research is an explanative study which is a kind of research design aiming to explain variables which are being observed and the relationship between one variable to 
another variable. The characteristic of this study is replicative; therefore, the result of hypothesis testing should be supported by previous studies and replied many times within another condition with similar situation. This study is about the effect of credit risk on bank profitability with efficiency as the intervening variable. The population of this study is 18 banks involving in Commercial Bank Based on Business Activities 3 within period study 2013-2015. Bank involving Commercial Bank Based on Business Activities 3 is not only a complex bank, but it is also a bank contributing a lot to the increase of Public Bank Profit gaining. The sampling technique used is a purposive sampling technique in which samples are chosen based on some considerations, such as: (1) the bank should involve in Commercial Bank Based on Business Activities 3 within 2013-2015 and having total asset more than 100 Billion in 2015, (2) the bank should have complete data which relates to the variables use in the study i.e. Non-Performing Loan (NPL), Allowance for Impairment Losses, Return on Asset (ROA), and Operating Expense to Operating Income.

Table 1 - Name of Banks Used as Research Sample

\begin{tabular}{|c|c|c|}
\hline No & Name of Bank & Total Asset (in millions) \\
\hline 1 & ClMB Niaga Bank & 233.235 .947 \\
\hline 2 & Permata Bank & 182.411 .535 \\
\hline 3 & Bank Tabungan Negara & 171.807 .592 \\
\hline 4 & Panin Bank & 169.140 .233 \\
\hline 5 & Danamon Indonesia Bank & 157.860 .188 \\
\hline 6 & Maybank Indonesia Bank & 148.933 .747 \\
\hline 7 & OCBC NISP Bank & 120.480 .402 \\
\hline
\end{tabular}

Source: Biro Riset Info bank, 2016 processed data.

Technique of data analysis used in this study is statistical descriptive analysis on research variables and Multiple Regression Analysis (MRA). In this study, there are two independent variables, one dependent variable, and 1 intervening variable. The independent variables in this study are Credit risk involving Non-Performing Loan (NPL) and Allowance for Impairment Losses. The dependent variable is bank profitability involving Return on Asset (ROA) ratio. The last, the intervening variable is Operating Expense to Operating Income. In this case, the steps of doing Multiple Regression Analysis (MRA) are as the following:

Partial Determination Coefficient $\left(r^{2}\right)$. The purpose of this test is to measure the contribution of dependent variable partially in affecting dependent variable.

- $r^{2}$ value is between 0 and $1\left(0<r^{2}<1\right)$

- The largest $r^{2}$ value shows dominant variable in explaining or affecting dependent variable.

If $r^{2}$ is 0 , there will be no impact contributed by independent variable on dependent variable. On the other hand, if $r^{2}$ is 1 , the percentage of effect contribution given by independent variable to dependent variable is perfect. Besides, this determination coefficient $\left(r^{2}\right)$ can be used to know the change of the percentage of independent variable $(X)$ which is caused by dependent variable $(\mathrm{Y})$.

Doing Partial Testing (t-test). T-test is used to examine whether partially credit risk in MRA model affects bank profitability significantly. Besides, it will also compare the value of $t_{\text {calculation }}$ and $t_{\text {table }}$ or see $P$ value of each variable. Therefore, it can be found whether the hypothesis is significant or not. If $\mathrm{t}_{\text {calculation }}>\mathrm{t}_{\text {table }}$ or $\mathrm{Sig}<.05$, it can be concluded that $\mathrm{HO}$ is rejected, whereas $\mathrm{H} 1$ is accepted which means that credit risk partially affects bank profitability. On the other hand, if $t_{\text {table }}<t_{\text {table }}$ or Sig $>.05$, it can be concluded that $\mathrm{HO}$ is accepted, whereas $\mathrm{H} 1$ is rejected which means that credit risk partially does not affect bank profitability.

Testing on Intervening Variable (Path Analysis). Path analysis is used because there is a possible relationship among variables with linier model. Efficiency is used as the intervening variable because the effect of NPL and Allowance for Impairment Losses on profitability can relate conceptually with efficiency ratio. Theoretically, the effect of NPL and Allowance for Impairment Losses on profitability can be seen directly, but it can be seen 
through the efficiency too. In this case, the level of confidence used is $95 \%$ and the alpha is $5 \%$. The analysis technique used to examine the existence of intervening is structural equation system with path analysis which can be seen as the following.

Structural equation to test the first hypothesis:

- $Y_{1}=\alpha 11 . X_{1}+\alpha 12 . X_{2}+e Y_{1}$

- $Y_{1}=$ efficiency

- $X_{1}=$ NPL

- $X_{2}=$ ALLOWANCE FOR IMPAIRMENT LOSSES

- $\alpha_{11}=$ path coefficient $X_{1}$ to $Y_{1}$

- $\alpha_{12}=$ path coefficient $X_{2}$ to $Y_{2}$

- $\quad \mathrm{eY}_{1}=$ path coefficient of error variable of the first model

Structural equation to test the second hypothesis:

- $Y_{2}=\alpha 21 . X_{1}+\alpha 22 . X_{2}+\alpha 1 . Y_{2}+e Y_{2}$

- $Y_{2}=$ profitability

- $Y_{1}=$ efficiency

- $X_{1}=$ NPL

- $X_{2}=$ ALLOWANCE FOR IMPAIRMENT LOSSES

- $\alpha_{21}=$ path coefficient $X_{1}$ to $Y_{1}$

- $\alpha_{22}=$ path coefficient $X_{2}$ to $Y_{2}$

- $\alpha_{1}=$ path coefficient $Y_{1}$ to $Y_{2}$

- $\mathrm{eY}_{1}=$ path coefficient of error variable of the first model

The calculation of indirect effect to test the third hypothesis:

- Indirect effect $X_{1}$ to $Y_{2}$ through $Y_{1}=\alpha_{11} \times \alpha_{1}$

- Indirect effect $X_{2}$ to $Y_{2}$ through $Y_{1}=\alpha_{12} \times \alpha_{1}$

\section{RESULTS AND DISCUSSION}

Based on the report of quarter financial report used in the sample of this study, there are Non-Performing Loan (NPL) and Allowance for Impairment Losses, the Operating Expense to Operating Income and Return on Asset (ROA) ratio. The minimal, maximal, mean, and standard deviation $(\delta)$ value of each variable can be seen in Table 2.

Table 2 - Descriptive Statistic

\begin{tabular}{|l|c|c|c|c|c|}
\hline \multicolumn{1}{|c|}{ Variable } & $\mathrm{N}$ & Minimum & Maximum & Mean & Std. Deviation \\
\hline NPL & 84 & 0.00 & 3.83 & 1.3740 & 1.03159 \\
Allowance for Impairment Losses & 84 & 0.89 & 3.74 & 1.6588 & 0.66043 \\
Operating Expense to Operating Income & 84 & 69.75 & 98.86 & 84.5313 & 6.62351 \\
ROA & 84 & 0.16 & 4.93 & 1.6175 & 0.79823 \\
Valid N (list wise) & 84 & & & & \\
\hline
\end{tabular}

Determination Coefficient $\left(r^{2}\right)$. Determination coefficient $\left(r^{2}\right)$ is prediction ability of each variable used, such as the percentage of effect contributing NPL ratio on ROA is $6.9 \%$, Allowance for Impairment Losses ratio ROA is $0 \%$, NPL toward Operating Expense to Operating Income is $9.7 \%$, Allowance for Impairment Losses toward Operating Expense to Operating Income is $1.8 \%$, and Operating Expense to Operating Income towards ROA is $78.5 \%$. On the other hand, the rest percentage is affected by other variables which are excluded from this study.

Path Analysis Test. T-test is used to test the hypotheses which partially elicit the effect of two independent variables (NPL and Allowance for Impairment Losses) on the dependent variable (Operating Expense to Operating Income).

Based on the table 3, it is found that the significant value of NPL is .004 with a .05 level of significance. It shows that the significance value of NPL is lower than a .05 meaning that NPL variable significantly affects Operating Expense to Operating Income variable. On the other hand, the significance value of Allowance for Impairment Losses is .238 with a .05 level 
of significance. It shows that Allowance for Impairment Losses does not significantly affect Operating Expense to Operating Income variable.

Table 3 - Partial Test (T-Test) of NPL and Allowance for Impairment Losses on Operating Expense to Operating Income

Coefficients $^{\mathrm{a}}$

\begin{tabular}{|l|c|c|c|c|c|}
\hline \multirow{2}{*}{ Model } & \multicolumn{2}{|c|}{$\begin{array}{c}\text { Unstandardized } \\
\text { Coefficients }\end{array}$} & Standardized Coefficients & \multirow{2}{*}{$\mathrm{t}$} & \multirow{2}{*}{ Sig. } \\
\cline { 2 - 5 } & $\mathrm{B}$ & Std. Error & Beta & & \\
\hline (Constant) & 79.754 & 2.064 & & 38.650 & .000 \\
1 NPL & 1.968 & .673 & .306 & 2.925 & .004 \\
Allowance for Impairment Losses & 1.250 & 1.051 & .125 & 1.190 & .238 \\
\hline
\end{tabular}

Dependent: Operating Expense to Operating Income.

The Result of Regression Analysis:

Table 3: Indirect Coefficient

\begin{tabular}{|l|c|c|c|c|c|}
\hline \multirow{2}{*}{ Model } & \multicolumn{2}{|c|}{$\begin{array}{c}\text { Unstandardized } \\
\text { Coefficients }\end{array}$} & Standardized Coefficients & \multirow{2}{*}{$\mathrm{t}$} & \multirow{2}{*}{ Sig. } \\
\cline { 2 - 5 } & $\mathrm{B}$ & Std. Error & Beta & & \\
\hline (Constant) & 10.601 & .526 & & 20.159 & .000 \\
\multirow{2}{*}{$\mathrm{NPL}$} & .011 & .041 & .014 & .268 & .789 \\
$\mathrm{n}$ Allowance for Impairment Losses & .140 & .061 & .116 & 2.279 & .025 \\
Operating Expense to Operating Income & -.109 & .006 & -.906 & -17.003 & .000 \\
\hline
\end{tabular}

Dependent: ROA Variables.

Path coefficient model II is about the effect of NPL, Allowance for Impairment Losses, and Operating Expense to Operating Income variable on ROA. The significance value of the three variables are: $\mathrm{X} 1$ (NPL) is .789 showing that NPL through Operating Expense to Operating Income does not significantly affect ROA with beta .014, X2 (Allowance for Impairment Losses) has significance value .025 lower than significance value a .05 meaning that Allowance for Impairment Losses through Operating Expense to Operating Income affects ROA significantly with beta value .116, and significance value of Operating Expense to Operating Income is .000 showing that Operating Expense to Operating Income affects ROA significantly with beta value .906 .

The Scale of Impact:

Table 4 - For NPL Variable

\begin{tabular}{|l|c|}
\hline Direct Impact of NPL on ROA & 0,014 \\
\hline $\begin{array}{l}\text { Indirect Impact of NPL on ROA through Operating Expense to Operating Income } \\
\text { as the intervening variable .306 x .906 }\end{array}$ & 0,277 \\
\hline Total Impact of NPL on ROA & 0,291 \\
\hline
\end{tabular}

Table 5 - For Allowance for Impairment Losses Variable

\begin{tabular}{|l|c|}
\hline Direct Impact of Allowance for Impairment Losses on ROA & 0,273 \\
\hline $\begin{array}{l}\text { Indirect Impact of Allowance for Impairment Losses on ROA through Operating Expense } \\
\text { to Operating Income as the intervening variable 0,125 x 0,906 }\end{array}$ & 0,113 \\
\hline Total Impact of Allowance for Impairment Losses on ROA & 0,229 \\
\hline
\end{tabular}

The results show that the value of direct impact of NPL toward the profitability ROA which is only .014 is able to increase up to .277 if the indirect impact is reviewed through the efficiency of Operating Expense to Operating Income. The increase of the effect from the intervening variable causes the total impact of NPL on profitability ROA is .291. This result is different from the impact of Allowance for Impairment Losses on profitability ROA with 
Operating Expense to Operating Income efficiency variable as the intervening variable. The value of direct impact of Allowance for Impairment Losses on profitability ROA is only .116 which, in fact, the impact decreases up to .113. This decrease from the intervening variable causes the total impact of Allowance for Impairment Losses on profitability ROA is .229.

The result of path analysis test shows that the profitability with credit risk represented by NPL variable as the defining factor should consider Operating Expense to Operating Income efficiency variable as the intervening variable. In this case, some studies treat Operating Expense to Operating Income efficiency variable as the independent variable, not as the intervening variable. If Operating Expense to Operating Income efficiency variable is as the independent variable, the role of credit risk to increase profitability ROA value is low. On the other hand, it will be different if Operating Expense to Operating Income efficiency variable is as the intervening variable, the role of credit risk in increasing profitability ROA will increase significantly. This result also shows that the increase of profitability ROA is not enough by only minimizing the credit risk by decreasing NPL. It should be followed by efficiency improvement. If inefficiency occurs, the increase of credit risk (NPL) will not contribute more to the profitability ROA. The banks involved in Commercial Bank Based on Business Activities 3 which become the samples of this study should consider the result of this study so that they will be able to decide good strategies in order to increase profitability ROA. Moreover, the result of the study shows that the increase of credit risk NPL can increase the profitability ROA if it is followed by the effort to be efficient. In this case, the role of efficiency Operating Expense to Operating Income in mediating the relationship between credit risk NPL and profitability ROA is very high. The evidence is that the scale of total credit risk impact is significant enough after gaining more indirect impact through Operating Expense to Operating Income efficiency.

However, it is different from Allowance for Impairment Losses variable which does not have significant impact through Operating Expense to Operating Income efficiency as the intervening variable. Allowance for Impairment Losses variable as the defining factor does not need to consider Operating Expense to Operating Income efficiency variable as the intervening variable because the result show that the increase of profitability ROA is enough by only minimizing the credit risk by lowering Allowance for Impairment Losses without the improvement on the efficiency of bank business activities. It occurs because the reserved fund to cover the losses has run for a year. The role of Operating Expense to Operating Income efficiency in mediating the relationship between credit risk Allowance for Impairment Losses and profitability ROA does not affect significantly. It is shown that the scale of the total credit risk impact which decreases is significant enough after gaining indirect impact through Operating Expense to Operating Income efficiency.

\section{CONCLUSION AND SUGGESTIONS}

Based on the regression analysis, some of the hypotheses are accepted and the others are rejected. In other words, there is significant impact and not significant impact. Therefore, it can be concluded that: (1) Non-Performing Loan (NPL) ratio has positive, significant effect on Operating Expense to Operating Income efficient ratio, (2) Allowance for Impairment Losses ratio has positive, not significant impact on Operating Expense to Operating Income efficiency ratio, (3) Non-Performing Loan (NPL) ratio has positive, not significant effect on profitability, (4) Allowance for Impairment Losses ratio has positive, significant impact on profitability, (5) Operating Expense To Operating Income efficiency ratio has negative, significant impact on profitability, (6) Non-Performing Loan (NPL) ratio affects negatively and significantly on profitability with Operating Expense To Operating Income efficiency as the intervening variable, (7) Allowance for Impairment Losses ratio affects negatively and does not affect significantly on profitability with Operating Expense To Operating Income efficiency as the intervening variable. Finally, regarding to the results of this study, future researchers should add other ratios which can be used to measure credit risk and profitability and should broaden the period of research period and provide more banks to be used as the research subject. Moreover, the management of bank should be more aware of lending by always 
implementing prudential principles and deeper mitigation of credit risk. Bank should be able to do efficient business activities to mitigate the credit risk so that it can affect the ability of bank in gaining profit.

\section{REFERENCES}

1. Berger, A. N. (1994). Did risk-based capital allocate bank credit and cause a "credit crunch" in the United States?. Journal of Money, credit and Banking, 26(3), 585-628.

2. Christensen, T. E., Paik, G. H., \& Stice, E. K. (2008). Creating a bigger bath using the deferred tax valuation allowance. Journal of Business Finance \& Accounting, 35(5-6), 601-625.

3. Fight, A. (2004). Credit risk management. Elsevier.

4. Hasan, I., \& Wall, L. D. (2004). Determinants of the Loan Loss Allowance: Some Cross-Country Comparisons. Financial review, 39(1), 129-152.

5. Hu, X., Gao, J., Li, F., Lv, W., Zhang, X., \& Zhang, Z. (2012). U.S. Patent Application No. $12 / 600,978$.

6. Irawati, S. (2006). Manajemen Keuangan. Cetakan Kesatu. Bandung,: PT.Pustaka

7. Jesus, S., \& Gabriel, J. (2006). Credit cycles, credit risk, and prudential regulation.

8. Kasmir, 2008. Bank dan Lembaga Keuangan Lainnya. Jakarta: Airlangga

9. Kuncoro \& Suhardjono, (2002). Manajemen Perbankan, Teori dan Aplikasi

10. Louzis, D. P., Vouldis, A. T., \& Metaxas, V. L. (2012). Macroeconomic and bank-specific determinants of non-performing loans in Greece: A comparative study of mortgage, business and consumer loan portfolios. Journal of Banking \& Finance, 36(4), 1012-1027. Lukman, D. (2005). Manajemen Perbankan. Jakarta: Ghalia Indonesia

11. Malintan, R., \& Herawati, T. (2012). Pengaruh Current Ratio (Cr), Debt To Equity Ratio (Der), Price Earning Ratio (Per), Dan Return On Asset (Roa) Terhadap Return Saham Perusahaan Pertambangan Yang Terdaftar Di Bursa Efek Indonesia Tahun 2005-2010. Jurnal IImiah Mahasiswa FEB, 1(1).

12. Noman, A. H. M., Pervin, S., Chowdhury, M. M., \& Banna, H. (2015). The effect of credit risk on the banking profitability: a case on Bangladesh. Global Journal of Management And Business Research.

13. Zou, Y., \& Li, F. (2014). The Impact of Credit Risk Management on Profitability of Commercial Banks: A Study of Europe. 